\title{
院内保育所における流行性角結膜炎の集団発生に対する 感染対策チームの介入効果
}

\author{
國領 俊之 ${ }^{1,2)} \cdot$ 木下 桂1,3) $\cdot$ 芳尾 邦子1,3) · 福本知代子1,4) $\cdot$ 南部 卓三1,5)
}

\section{Effect of Intervention by the Infection Control Team on an Outbreak of Epidemic Keratoconjunctivitis in a Hospital Day-Care Center}

\begin{abstract}
Toshiyuki Konuryo ${ }^{1,2)}$, Katsura Kinoshita ${ }^{1,3)}$, Kuniko Yoshio ${ }^{1,3)}$, Chiyoko Funumoto ${ }^{1,4)}$ and Takuzo NAnbu ${ }^{1,5)}$
1) Infection Control Team, 2) Department of Pharmacy, ${ }^{3)}$ Department of Nursing, ${ }^{4}$ Department of Clinical Laboratory,

5) Department of Internal Medicine, Kohka Public Hospital
\end{abstract}

(2013 年 11 月 5 日 受付 · 2014 年 5 月 16 日 受理)

要旨

公立甲賀病院では, 2011 年 6 月に院内保育所において流行性角結膜炎 (EKC) が集団発生し， 1 週間の院内保育所閉鎖を行った. 院内保育所での EKC 集団発生に対して感染対策チーム(ICT)が 介入した報告は見当たらない，本論文では，EKC 集団発生に対するICT の介入効果について検討 を行った. 集団発生の原因として, ICT の介入が遅れたこと, 接触感染予防が不十分であったこ とが考えられた．ICT 介入による予防対策として，(1)早期からのICT の介入，(2)早期の感染患 児の隔離及び受診と帰宅，(3)接触感染対策及び環境消毒の強化を行った．ICT の介入後(1)〜 (3) は実施されて打り，EKC 発症率の差は有意ではなかったものの，2011年 $26 \%$ から 2012 年 $8 \%$ に 低下した $(\mathrm{p}=0.093)$. 本研究から, 早期の $\mathrm{EKC}$ 発症園児の隔離と受診及び州宅, 接触感染対策及 び環境消毒の強化は，院内保育所に扔いて EKC 集団発生防止に必要であることが示唆された。

Key words : 流行性角結膜炎, 院内保育所, 集団発生, 感染対策チーム

序文

流行性角結膜炎 (epidemic keratoconjunctivitis: EKC) はアデノウイルスの感染によって起こる感染症である. アデノウイルスの感染力は非常に強力であり, 接触感染 によって伝播することから, 感染対策として最も重要で 基本となる対策は「手洗い」等の手指衛生であり ${ }^{1)}$, 接 触感染防止対策として次亜塩素酸ナトリウムによる医療 器具の消毒や消毒用エタノールによる環境消毒を併せて 実施することが必要である22.

公立甲賀病院 (以下, 当院) では, 入院外来病棟とは別 棟に院内保育所(ひまわり園)を設置し, 当院職員を対象 とした託児業務を行っている. 2011 年 6 月に当院院内 保育所託児 (以下, 園児) が EKC を発症した院内保育所

公立甲賀病院 ${ }^{1}$ 感染対策チーム, 2) 薬剤部, 3) 看護部, ${ }^{4}$ 臨床 検査課, 5) 内科 に対して感染対策チーム(infection control team: ICT) が介入したにもかかわらず EKCの集団発生を起こし， 院内保育所の閉鎖に至った事例を経験した。過去に，細 田らは, 院内外で $\mathrm{EKC}$ が流行し $\mathrm{EKC}$ の発生源と想定 された院外医療関連施設や地域の保育所に対して感染対 策委員会が保健所と協力して介入し地域流行を終息させ たことを報告している3)。しかし，院内保育所に执いて 発生した EKC の集団発生に対して院内感染制御部門に よる介入事例に関する報告は, 我々の知る限り見当たら ない，また，入院病棟に扔いてアデノウイルス結膜炎の 集団発生を終息させた報告はあるものの ${ }^{4)}$, 院内保育所 を対象とした報告は見当たらない，そこで，本論文では 当院院内保育所に扔いて発生した EKC 集団発生が終息 するまでの経緯を紹介するとともに，EKC 集団発生に 対する ICTの介入効果について検討を行ったので報告 する。 
な抢, 本論文の公表に際して, 臨床研究に関する倫理 指針及び疫学研究に関する倫理指針に基づき, 当院医学 研究 - 医療行為倫理委員会の承認を得ている(受付番号 $268: 2013$ 年 11 月 15 日承認).

\section{材料と方法}

\section{2011年に発生した EKC 発生園児数の推移}

当院は病床数 442 (2011 年当時)の滋賀県甲賀 - 湖南 両市に打ける地域中核病院として機能しており, 病院職 員の 0 ３歳児を対象とした院内保育所を併設してい る. 託児数は, 2011 年 23 人, 2012 年 25 人であった.

当院院内保育所において EKC が集団発生した期間の 2011 年 6 月 1 日 7 月 13 日を 2011 年調查対象期間と して, 当院院内保育所に打ける $\mathrm{EKC}$ 発症園児数を経時 的に調査した.

$\mathrm{EKC}$ の疾患定義として, 眼脂・結膜充血・眼痛のい ずれかの症状を呈し, かつ原則的にアデノウイルス抗原 検查 (アデノチェック®)が陽性を示し, 眼科医によって $\mathrm{EKC}$ と診断されたものを $\mathrm{EKC}$ 発症患者と定義した。 $\mathrm{EKC}$ 発症園児の臨床症状とアデノウイルス抗原結果を 表 1 に示す。な押，アデノチェック『よるる抗原検查を 実施しなかった園児 2 人は $\mathrm{EKC}$ 発症者が同一家庭内に いたこと, または同日アデノチェック陽性となり $\mathrm{EKC}$ と診断した他の院内保育所園児と同じ所見であったこと から，アデノチェック®を用いた検査を実施することな く眼科医の判断によって $\mathrm{EKC}$ と診断した症例である.

\section{ICT の介入事項}

2011 年及び 2012 年の院内保育所における EKC 流行 時期の ICT の介入項目について, ICT の業務記録等か ら情報の抽出を行った。 2012 年の調査期間は EKC 発 生日を含めた 2011 年とほぼ同期間とした.

3. EKC 発症園坚数と同時期の甲賀定点当たり患者数 甲賀地域内流行の指標として, 打上そ調査期間に該当 する期間 (第 22 27 週)の甲賀保健所管内に打ける定点 当たり患者数 5 を甲賀定点当たり患者数として調査した.

\section{表 1 EKC 発症園児一覧}

\begin{tabular}{|c|c|c|c|c|c|}
\hline No. & 年齢 & 性別 & $\begin{array}{c}\text { 発症旦 } \\
\text { (2011 年) }\end{array}$ & 臨床症状 & $\begin{array}{c}\text { アデノウ } \\
\text { イルス抗 } \\
\text { 原検查注) } \\
\text { 結果 }\end{array}$ \\
\hline 1 & 1 歳 9 ヶ月 & 男 & 6 月 21 日 & 結膜充血 & 陽性 \\
\hline 2 & 1 歳 2 ヶ月 & 女 & 6 月 27 日 & 結膜充血 & 陽性 \\
\hline 3 & 2 歳 1 ヶ月 & 男 & 6 月 29 日 & 結膜充血 & 陽性 \\
\hline 4 & 2 歳 2 ヶ月 & 男 & 6 月 29 日 & 結膜充血·眼脂 & 実施せず \\
\hline 5 & 2 歳 2 ヶ月 & 男 & 6 月 29 日 & 結膜充血·眼脂 & 実施せず \\
\hline 6 & 1 歳 1 ヶ月 & 男 & 7月 6 日 & 結膜充血 & 陽性 \\
\hline
\end{tabular}

\section{EKC 発症率}

各年の $\mathrm{EKC}$ 発症率 $(\%)$ は「 $(\mathrm{EKC}$ 発症園児数/託児

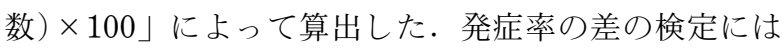
$\chi^{2}$ 検定を用い，危険率両側 $5 \%$ 未満を有意な差として評 価した。

5. 院内保育所の EKC に対する感染対策上の問題点 之改善策

EKC に対する感染対策上の問題点を抽出し，その改 善策の検討を行った(表 2). 眼症状等の EKC 症状の確 認は EKC 集団発生前から登園時に包括的に行われてい た. $\mathrm{EKC}$ 症状発現後帰宅までの時間は, 改善策検討前 (2011 年) 約 7 時間, 改善後 (2011 年院内保育所再開後 及び 2012 年)約 1.5 時間であった.

\section{6. 院内保育所における環境消毒}

通常の院内保育所の環境整備及び清掃は契約業者が行 い，園児が污した部分は院内保育所職員が第 4 級アン モニウム塩含浸の環境除菌シートを用いて環境清拭(消 毒)を行った．EKC 発症園児が発生した後は，ICT の 指示の下， $0.1 \%$ 次亜塩素酸ナトリウム液を用いて園児 や職員が日常的に手の触れる環境(ドアノブ，手すり， 壁, 床, プレイルーム, 棚, 玩具など)を清拭消毒し た．次亜塩素酸ナトリウムが使用できない環境(金属製 品など)は， $80 \%$ エタノール含浸除菌シートを使用し， 清拭消毒不可能なもの(リネン類)は洗濯または洗浄した 後, 天日干しを行った．院内保育所閉鎖直後及び再開前 日にも同様の環境消毒を実施した。

\section{結 果}

\section{2011年に発生した EKC 発生園児数の推移}

当院院内保育所において，2011 年 6 月 21 日に EKC 初発園児が発生してから院内保育所を閉鎖後再開した 2011 年 7 月 13 日までの期間の EKC 発生園児数の経時

表 2 院内保育所の EKC に対する感染対策上の問題点と改善策

\begin{tabular}{|c|c|c|}
\hline 発生時 & 問 題 点 & 改 善 策 \\
\hline $\mathrm{ICT}$ & $\begin{array}{l}\text { ICT の介入まで報告 } \\
\text { なし }\end{array}$ & $\begin{array}{l}\text { EKC疑い園児発生 } \\
\text { 後直ちに報告 }\end{array}$ \\
\hline $\begin{array}{l}\text { EKC 発症園児 } \\
\text { の対応(受診前) }\end{array}$ & $\begin{array}{l}\text { 眼症状等観察の下, } \\
\text { 怹の園巟と室で託 } \\
\text { 贸 }\end{array}$ & 別室に隔離して託児 \\
\hline $\begin{array}{l}\text { 保護者 } \\
\text { 員)へ }\end{array}$ & $\begin{array}{l}\text { 登園時と比較して症 } \\
\text { 状悪化時に連絡 }\end{array}$ & $\begin{array}{l}\text { EKC 症状確認後, } \\
\text { 至急に連絡 }\end{array}$ \\
\hline $\begin{array}{l}\text { EKC 発症園児 } \\
\text { の対応 (受診後) }\end{array}$ & $\begin{array}{l}\text { 受診後, 就業時刻ま } \\
\text { で託留 } \\
\text { [帰宅の要請なし】 }\end{array}$ & $\begin{array}{r}\text { 受診後, 直ちに帰宅 } \\
\text { [帰宅を要請] }\end{array}$ \\
\hline
\end{tabular}

環境消毒·手指翌日 (ICT介入後) EKC 疑い園児発生

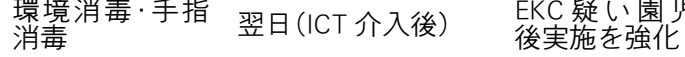

EKC : epidemic keratoconjunctivitis(流行性角結膜炎), ICT : infection control team. 


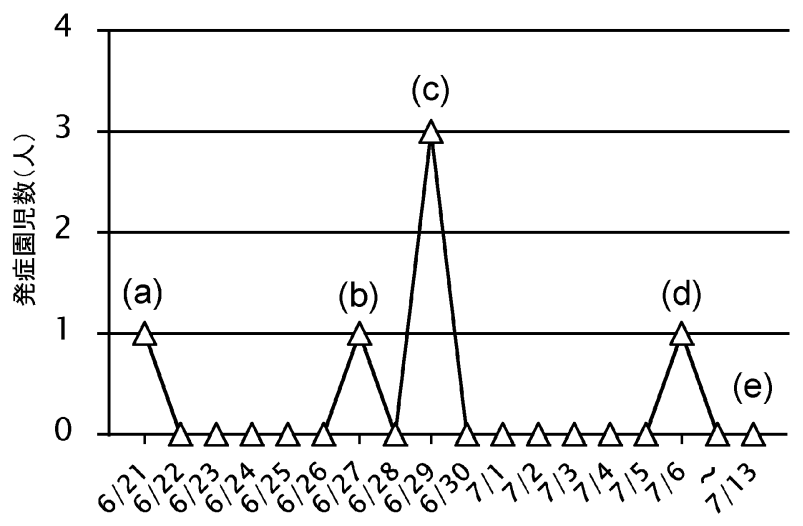

図 12011 年における EKC 発症園児数の経時的推移 図中 (a) (e) は, 以下の院内保育所の状況を示す. (a) : $\mathrm{EKC}$ 初発園児発生, (b) : EKC 発症園児 2 人目発生, (c)：6 月 30 日から看護師の託児受け入れ中止を決定， (d) : 院内保育所閉鎖 $(7$ 月 6 日), (e) : 院内保育所再開 $(7$ 月 13 日).

的推移を図 1 に示す。なお，図 1 に当該期間中に拈ける 院内保育所の状況 $(\mathrm{a}) \sim(\mathrm{e})$ を併せて記載した.

\section{ICT の介入事項}

I. 2011年

2011 年における EKC 発生状況と ICT の介入事項に ついて時系列で以下に示す。

6 月 21 日 (day 1)：院内保育所に抢いて EKC 初発園 児発生(図 1, (a))

6 月 22 日 (day 2)：EKC 初発園児の発生から 1 日経 過後に ICT が EKC 発生を把握し介入を開始. 院内保 育所に対して, EKC の病態, 潜伏期間等の情報提供を 行うとともに, 手指消毒, 環境消毒の必要性を説明し消 毒薬の使用を指示.

6 月 24 日 (day 4): 院内保育所, 眼科 - 小児科の外 来. 入院病棟に対して, 通常使用する第 4 級アンモニ ウム塩含浸環境除菌シートではなく，80\%エタノール 含浸除菌シートを使用するように指示.

6 月 25 日 (day 5)：院内に $\mathrm{EKC}$ 発生に対する注意喚 起. $\mathrm{EKC}$ に関するポスター作成及び院内揭示, 患者用 説明書配布開始.

6 月 27 日 (day 7$)$ : 院内保育所にて $\mathrm{EKC}$ 発症園児 2 人目発生 (図 1, (b))

6 月 29 日 (day 9$)$ : 院内保育所に打いて 6 月 27 日 (day 7 ) からの 3 日間で $\mathrm{EKC}$ 発症園児が 4 人に急増し たことから，院内感染対策委員会 (infection control committee: ICC) は日常業務への影響を考慮した上で， 6 月 30 日 (day 10) から主な託児職員である看護師の託 児受け入れの中止を決定 (図 1, (c)). ICT は, 看護師 託児受け入れ中止に伴う託児職員の休職に対する協力を 各看護師長に要請.

7 月 4 日 (day 14) : 看護師託児受け入れ再開時の
EKC 集団発生防止対策について，下記の事項を院内保 育所に指示.〔1〕環境消毒を継続すること；〔2〕登園 時に EKCの症状を確認し, 疑わしい場合は託児せず, 保護者 (病院職員)に眼科・小巟科受診(及び䚻宅)を要請 すること；[3]託児中，園児に $\mathrm{EKC}$ 疑いの症状が発現 した場合は別室に隔離し, 早急に保護者(病院職員)に連 絡し，眼科受診及び帰宅を要請すること，また，看護師 託児受け入れ再開後に EKC 集団発生防止対策が迅速に 実施できるように，職員の早退及び休職等に対する協力 を各看護師長に再度要請.

7 月 6 日 (day 16)：院内保育所において託児を継続し た園児から EKC 1 人が発生したことから， ICT は全て の園児を対象として 7 月 6 日から院内保育所閉鎖を決 定(図 1, (d))

7 月 12 日 (day 22) : 院内保育所保育士が院内保育所 閉鎖中の各園児の状況を確認した結果から，ICT は集 団感染が終息したと判断し，7月 13 日(day 23) から院 内保育所再開を決定.

7 月 13 日 (day 23): 院内保育所再開(図 1, (e)).

7 月 14 日 (day 24) 以降: $\mathrm{EKC}$ 疑い園児は発生せず. $\mathrm{EKC}$ 感染防止対策に関する院内感染対策のマニュアル 改訂を行い, 院内保育所に周知を実施.

\section{2012年}

2012 年に打ける EKC 発生状況と ICT の介入事項に ついて時系列で以下に示す.

6 月 5 日 (day 1)：病院職員が EKCを発症. 即日, 当 該職員は直ちに就業停止. ICT は院内 LAN において院 内各部署に対して $\mathrm{EKC}$ 発生に関する注意喚起を行う. また，ICT は院内保育所での集団発生を想定して，院 内保育所に対して $\mathrm{EKC}$ 集団発生防止対策の実施事項の 確認及び指示を行う.

6 月 12 日 (day 8)：託児中に $\mathrm{EKC}$ 疑い園児が発生. 院内保育所職員は, ICT からの指示通り当該 $\mathrm{EKC}$ 発症 園児を院内保育所内の別室に隔離し, 保護者(病院職員) に眼科受診 (及び帰宅) を要請し実施される. ICT は院 内保育所に拈いて $\mathrm{EKC}$ 集団発生防止対策及び環境消毒 が実施されていることを確認。

6 月 13 日 (day 9) : 保育士の判断で, 院内保育所内の 環境消毒及び手指消毒の強化を実施.

6 月 15 日 (day 11)：6 月 12 日 (day 8) と同様に, $\mathrm{EKC}$ 疑い園児が発生. 院内保育所職員は迅速に対応 し，保護者(病院職員)に対して眼科受診・帰宅を要請 し, 実施される。その旨, 院内保育所から ICT に報告 あり。

6 月 16 日 (day 12) 以降: EKC 疑い園児は発生せず.

\section{EKC 発症園児数と同時期の甲賀定点当たり患者 数の比較}

2011 年 6 月 1 日〜 7 月 13 日及び 2012 年同時期の院 

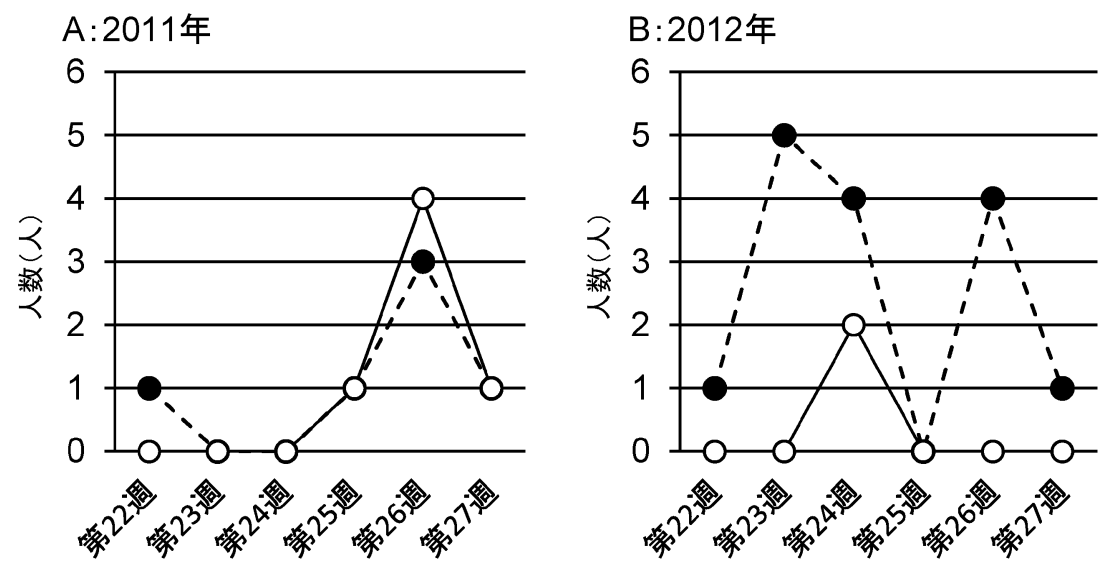

図 2 院内保育所における EKC 発症園児数と甲賀定点当たり患者数の推移

図中シンボルは院内保育所 (一○一), 甲賀定点当たり患者数(--゚-ー)を示す. EKC : epidemic keratoconjunctivitis(流行 性角結膜炎). 託児園児数 : 2011 年 23 人, 2012 年 25 人.

内保育所に㧍ける $\mathrm{EKC}$ 発症園児数と該当する時期 (2011 年第 $22 \sim 27$ 週)の甲賀定点当たり患者数の推移 について図 2 に示す.

\section{EKC 発症率}

2011 年及び 2012 年の $\mathrm{EKC}$ 発症率はそれぞれ $26 \%$ (EKC 発症園児数 6 人/託児数 23 人) 及び $8 \%(2 / 25)$ で あった，発症率は低下したが，その差は有意ではなかっ た $\left(\mathrm{p}=0.093, \chi^{2}\right.$ 検定 $)$.

\section{考察}

保育所に抢ける感染症対策に関する指針として，厚生 労働省は平成 21 年 8 月に「保育所に抢ける感染症対策 ガイドライン一平成 21 年 8 月一」6)を作成している. 保 育所に打ける感染症対策は本ガイドラインに基づいて実 施されていると思われるが，平成 21 年 8 月の本ガイド ライン6)には EKC の感染対策に関する記述がされてい ない. 平成 24 年 11 月に改訂された本ガイドライン1)に $\mathrm{EKC}$ 感染対策に対する記述が追加されるまでは, 保育 所では EKC 感染対策に関する認識が低かった可能性が 考えられる. また, 当院 ICT においても院内保育所が 医療関連施設であることの認識は薄く, 院内保育所に対 して院内感染対策マニュアルが周知されていなかったの が現状であった。そのため, ICT は 2011 年において $\mathrm{EKC}$ 初発加 1 日経過後に眼科医師からの報告によっ て EKC の院内保育所発生を把握することとなり, 接触 感染に対する初動対策の遅れが院内保育所内での EKC 接触感染を招く危除性が考えられた。一般的に, 保育園 内では園児どうしが長時間濃厚に接触する機会が多く, 接触感染による集団発生を起こす危険性が高いことが想 定されることから，ICT は院内保育所に対して EKC 集 団発生防止対策に関する介入 (手指消毒や環境消毒の実 施)を行った。しかし，2011年第 25〜27 週の期間に院
内保育所における $\mathrm{EKC}$ 発症園児数が 6 人にまで増加 し，最終的に 7 日間の院内保育所閉鎖に至った(図 1).

2011 年第 $25 \sim 27$ 週に抢いて合計 6 人の $\mathrm{EKC}$ 院内保 育所発生が認められた原因として, 以下の二点が考えら れる. 一点目は甲賀定点当たり患者数から想定される地 域流行が園児によって院内保育所に持ち込まれていたこ と， EKC に対する接触感染防止対策の実施が遅れたこ と及び不十分であったことが考えられる。これらの対策 として, 院内保育園登園時・託児中の観察で $\mathrm{EKC} か ゙$ 疑 われる場合に迅速な別室隔離・診察要請等の対応や施設 内環境消毒の実施によって院内保育所内伝播を可能な限 り抑えることができると考えられる．二点目は，8～14 日とされるアデノウイルスの潜伏期間中7) に他園児に伝 播していた可能性が考えられる. しかし, 宿主内潜伏期 に必ずしも二次感染を成立させるために十分量のウイル スが放出されているとは限らないことから 2 , 潜伏感染 者を 2011 年集団発生の感染源と判断する根拠忹しい.

院内保育所閉鎖後, 集団発生予防対策を行うことを目 的として, 院内保育所における $\mathrm{EKC} に$ 対する感染対策 上の問題点と改善策の検討を行った．問題点として, ICTへの報告が遅れたこと, 接触感染防止対策が不十 分であったこと〔別室隔離が行われなかったこと，保護 者(病院職員)への連絡が遅れたことによって診療科受診 後も保育所内で継続した託児を行ったこと了, 環境消毒 及び手指消毒の実施が遅れたことが挙げられた。これら の問題点に対して, 接触感染予防対策を基本とした表 2 に示す改善策を行った。 その結果, 院内保育所再開時や 2012 年の院内保育所では, ICT への早期報告, EKC 発 症園児の別室隔離，早期の保護者への診療科受診 ·帰宅 要請, 環境消毒や手指消毒の強化等の接触感染対策が実 施されていた。 また， $\mathrm{EKC}$ 症状発現後診療科受診まで の時間は短縮されており， $\mathrm{EKC}$ 症状発現後の対応が迅 
速に行われていた. ICT は EKCが接触感染によって伝 播していくことを重視し, ウイルス性及び細菌性の有無 にかかわらず結膜充血等の眼症状が発現した場合は早急 に該当園児を別室隔離し早期の診療科受診を保護者(職 員)に要請することを院内保育所職員に指示した。ま た，眼科医による $\mathrm{EKC}$ 診断が得られた時点で $\mathrm{EKC}$ 感 染対策が有効に行わ扎るうに, 当該保護者(職員)の早 退及び休職に迅速に対応するよう，ICTの権限をもっ て各所属長に要請及び指示した。これらの ICTによる 介入効果によって, $\mathrm{EKC}$ 症状発現後診療科受診及び州 宅までの時間短縮が得られたと考えられる。 また，これ らの ICT 介入事項は当院の EKC 感染防止対策マニュ アルに追記し，次年の 2012 年においても有効に実施さ れていた.

地域流行の指標となる甲賀定点当たり患者数(第 22 27 週)の合計は 2011 年 5 人, 2012 年 15 人であり, 2011 年に比べて 2012 年の方が大きな地域流行が発生 していたと推察される(図 2). すなわち, 院内保育所内 への $\mathrm{EKC}$ 持ち込及園児数の増加及び保育所内伝播等に よって, 院内保育所 $\mathrm{EKC}$ 発生数が増加することが予想 される. 一方, 院内保育所に打的 $\mathrm{EKC}$ 発症率は, そ の差が有意ではなかったものの, 集団発生した 2011 年 26\%から集団発生予防策を実施した 2012 年同時期 8\% に低下したことから，ICT による EKC 集団発生に対す る介入効果が認められた可能性が示唆される.しかし, 限られた空間である院内保育所内 $\mathrm{EKC}$ 発症数と定点当 たり患者数として報告される市中発症 $\mathrm{EKC}$ 発症数は発 生・伝播の状況が異なると考えられるため, 両年の院内 保育所に抢ける $\mathrm{EKC}$ 発症状況を直接比較することは難 しい。また，2011年の保育所内集団発生によって園児 が EKC 抗体を獲得したために 2012 年の EKC 発症率 が低下した可能性は否定できない. 従って, 本研究結果 のみで 2011 年に比べて 2012 年の EKC 発症率が低下し た要因が ICT による直接的な介入効果によるものと判 断することは困難であると考えられた.

2011 年 $\mathrm{EKC}$ 初発園児発生日 6 月 21 日 (day 1) から 6 月 27 日 (day 7 )にかけて $\mathrm{EKC}$ 発症園児 2 人目が発生 し, その 2 日後である 6 月 29 日 (day 9)には EKC 発生 園児は合計 5 人まで急増し集団発生の様相を呈したこ とから, 院内保育所が主に託児を依頼されていた看護師 の託児受け入れを 6 月 30 日に中止したものの, 病院全 体の日常業務への影響を考慮して看護師を除く職員の託 児は継続して行うこととなり，全ての園児を対象とした 院内保育所閉鎖は約 1 週間後の 7 月 6 日となった.山 下らは, 感染性胃腸炎患者の隔離時期と院内集団感染発 生率に関する検討を行っており, 感染性胃腸炎発症を把 握した当日, 1 日後, 2 日後, 3 日後以降に患者隔離を 行った場合の大規模な集団感染発生率はそれぞれ $0 \%$,
9.1\%，40.0\%，100\%であり，3 日後以降の患者隔離で は大規模な集団感染を回避できなかったと報告してい る ${ }^{8)}$. 感染性胃腸炎の原因ウイルスの一種であるノロウ イルスの伝播形式は，その一部としてアデノウイルスと 同様に接触感染が関与していると考えられている. 両ウ イルスの感染力が同程度であると仮定した場合，院内保 育所閉鎖は患者隔離よりもむしろ入院病棟閉鎖に相当す ると考えられるものの, 「EKC 発症園児 2 人目発生日 (6月 27 日)から 2 日後 (6 月 29 日)」が大規模な集団感 染を回避するための院内保育所閉鎖を行う限界の期日で あったと推察される.

アデノウイルス結膜炎院内感染対策ガイドラインで は，入院病棟に拈いて 1 週間以内に 2 例目のアデノウ イルス結膜炎患者が発見された時点で院内感染が確定す る，とされている21. また，このガイドラインではアデ ノウイルス結膜炎が発生した場合，2週間は新規入院患 者を完全に中止し, 病棟環境消毒や診察機器の滅菌・消 毒を徹底的に行い, 病棟での最後の発病から 2 週間経 過した時点で入院再開を検討すること, とされてい $る^{2)}$. 院内保育所に招いても入院病棟と同様にこのガイ ドラインを適応した場合,「院内保育所の $\mathrm{EKC}$ 初発日 6 月 21 日から 1 週間以内に 2 人目が発症した日 $(6$ 月 27 日)の翌日 $(6$ 月 28 日)」が院内保育所閉鎖日に該当して いたことになる．仮に 6 月 28 日に院内保育所を閉鎖し た場合， EKC 発症園児 4 人を未然に防ぐことができた 可能性が考えられた.

院内保育所閉鎖期間中は，託児が行えないことが理由 で院内保育所に託児する病院職員出勤者数の低下を招 き, 病院職員全体(主に看護師)の労働力が低下すると推 測された。そこで，2011年における院内保育所閉鎖に よる出勤者数の減少が日常業務に与える影響について検 討するために，2011 年 6 月の職員時間外労働時間を 2012 年同時期と比較検討した結果, 両者に大きな差は 認められなかった(data not shown). 両者に差が認めら れなかった理由として，2011年には業務内容の見直し による病院全体として時間外労働の短縮が行われたこと, 2012 年には新病院移転に関わる会議等の時間外労働が 発生したことが挙げられる.すなわち, 実働職員数の減 少によって発生する時間外労働時間は上記の理由で相殺 されている可能性が考えられた.

以上，本論文では当院院内保育所に扔いて発生した $\mathrm{EKC}$ 集団発生が終息するまでの経緯を紹介するととも に, EKC 集団発生に対する ICT の介入効果について検 討を行ったＩCTの介入による早期の EKC 発症園児の 隔離 (と受診及び䚻宅), 接触感染対策及び環境消毒の強 化は, 他の病院内部署と同様に院内保育所においても $\mathrm{EKC}$ 集団発生防止に必要であると考えられた． EKC 集 団発生による院内保育所の閉鎖は, 公衆衛生上の問題だ 
けでなく, 本論文では示されなかったものの事実上の託 児職員の出勤制限による労働力の低下を招く可能性が考 えられる. 従って, 院内保育所は従来から実施されてき た院内感染対策部署である入院外来病棟等と同様に, 病 院内に打溜染症集団発生防止対策部署として重要視 する必要があると考えられる。

本論文の要旨は, 第 28 回日本環境感染学会総会(横浜)にお いて発表した.

利益相反について : 利益相反はない.

文献

1）厚生労働省 : 保育所に打ける感染症対策ガイドライン一 平成 24 年 11 月一. http: // www.mhlw.go.jp / bunya / kodomo/pdf/hoiku02.pdf : 平成 25 年 7 月 10 日現在

2) 日本眼科学会 : アデノウイルス結膜炎院内感染対策ガイ ドライン. http://www.nichigan.or.jp/member/guideline/adenovirus.jsp : 平成 25 年 7 月 10 日現在
3）細田昌良, 小松敏美，松下美幸：流行性角結膜炎に対す る地域社会と連携した感染対策の試み。環境感染誌 2008; 23(2): 140-4.

4）藤原理太郎, 三田村佳典, 田川 博, 大庭正裕, 橋本雅 人，鈴木康夫，他：アデノウイルス 4 型結膜炎の院内 感染. 日眼会誌 $2003 ; 107(7): 388-92$.

5）滋賀県感染症情報センター：患者情報． http://www. pref.shiga.lg.jp/e/ef45/kansen-c/kanja_jyouhou.html : 平成 25 年 7 月 10 日現在

6）厚生労働省 : 保育所における感染症対策ガイドライン一 平成 21 年 8 月一. http: // www.mhlw.go.jp / bunya / kodomo/pdf/hoiku02_0001.pdf : 平成 25 年 7 月 10 日 現在

7）国立感染症研究所：流行性角結膜炎とは. http://www. nih.go.jp/niid/ja/kansennohanashi/528-ekc.html : 平成 25 年 7 月 10 日現在

8）山下ひろ子，小山田玲子，奥 直子，西村正治，石黒信 久: 感染性胃腸炎患者の早期隔離と院内集団感染回避に 関する観察研究. 環境感染誌 2012; 27 (5): 333-41.

〔連絡先：=528-0074 滋賀県甲賀市水口町松尾 1256 番地 公立甲賀病院薬剤部 國領俊之

E-mail: toshi-k@umin.ac.jp]

\title{
Effect of Intervention by the Infection Control Team on an Outbreak of Epidemic Keratoconjunctivitis in a Hospital Day-Care Center
}

\author{
Toshiyuki KokUryo ${ }^{1,2)}$, Katsura Kinoshita ${ }^{1,3)}$, Kuniko Yoshio ${ }^{1,3)}$, Chiyoko Funumoto ${ }^{1,4)}$ and Takuzo NAnbu ${ }^{1,5)}$ \\ 1) Infection Control Team, ${ }^{2)}$ Department of Pharmacy, ${ }^{3)}$ Department of Nursing, ${ }^{4)}$ Department of Clinical Laboratory, \\ 5) Department of Internal Medicine, Kohka Public Hospital
}

\begin{abstract}
An outbreak of adenovirus-associated epidemic keratoconjunctivitis (EKC) occurred in the daycare center in our hospital, and the center was closed for a week in June 2011. This study documents the effect of intervention by the infection control team (ICT) on an outbreak of EKC in a hospital day-care center. This outbreak was caused by delayed intervention of the ICT and inadequate contact infection control. The recommended improved infection control measures were (1) early intervention of the ICT in the hospital day-care center, (2) early definition of cohorts of infected child patients followed by diagnosis and return home, and (3) enhanced adherence to contact infection control and environmental disinfection measures. After implementation of the control measures, the infection rate of EKC was reduced, but not significantly (26\% in 2011, $8 \%$ in 2012 ; $p$ $=0.093)$. This study suggests that early definition of cohorts of child patients followed by diagnosis and return home, and enhanced adherence to contact infection control and environmental disinfection measures may be essential to prevent an outbreak of EKC in a hospital day-care center.
\end{abstract}

Key words : epidemic keratoconjunctivitis, hospital day-care center, outbreak, infection control team 